\title{
MODERNIZATION AND MASS MEDIA EXPOSURE AMONG EDUCATED MUSLIM WOMEN: A STUDY OF BHOPAL DISTRICT
}

\author{
Mashooq Ah Challa ${ }^{1}$ and Dr.Usha Vaidya ${ }^{2}$ \\ ${ }^{1}$ M.Phil. Scholar Dept. of Sociology Rabindranath Tagore University Raisen (M.P) \\ ${ }^{2}$ HOD Humanities Rabindranath Tagore University Raisen (M.P)
}

DOI: 10.46609/IJSSER.2021.v06i02.021 URL: https://doi.org/10.46609/IJSSER.2021.v06i02.021

\begin{abstract}
Women have constituted important character in any society down the history. In the past women have been respected and enjoyed high status in society but at the same time they have witnessed cruelty, helplessness, violations and most suppressed character of the society. However, they have gone through the different phases of transformation. The women in present time are much stronger, confident, intelligent and organizer of the modern society. In this study we try to know what was the impact of Modernization and Mass media exposure on educated Muslim women in District Baramull and how Muslim women are getting modern or moving towards modernity. The other important research questions which we try to investigate in our study would be that What are the restriction faced by the Educated Muslim women with regard to education \& career and what are the restrictions imposed by the family members while using social networking sites or using mass media communication and why? Additionally, we are try to examine What are the various changes that Mass Media has bought up in approach of Muslim women towards work \& education. The expected outcome of the current research work would be that Modernization should have both positive as well as negative impact on Muslim women in District Baramulla. In the changing scenario, Muslim women are more exposed to the means of Mass Media communication. The other important outcome of the study would be that the pattern of mass media exposure shall be helpful in educated Muslim women in District Baramulla and the pattern of the mass media exposure shall lead towards modernization of the people.
\end{abstract}

\section{Introduction}

The world would be imperfect without the presence of women. Women have constituted an important and keystone character in the arch of any society down history. No doubt the Women has gone through several phases in the past and the history stands testimony that in the past women have been respected and enjoyed high status in society but at the same time, some phases of the women life have witnessed cruelty, vulnerability and most suppressed character of the 


\section{International Journal of Social Science and Economic Research}

ISSN: $2455-8834$

Volume:06, Issue:02 "February 2021"

society. There were so many ill practices, which were practiced in earlier times, which have mired the intellectual and social growth of women such as rights were very much limited in inheriting property. The boys were treated superior, as result male children were preferred to female children; women were having limited rights to remain unmarried women throughout their life. Marriage was forcibly imposed on them Child marriages were common, the custom of Devadas is was very famous in Indian History where the girls were dedicated to temples in the name of gods and goddesses. Even though the women were banned from provided the opportunity to attain high intellectual and spiritual standards in the past but with time they fought for their rights and raise their position in society (Anita, 2010). Down the stream of history, women established themselves as prominent and pivotal characters of society. Though they have gone through the phases of the Sati system, Child Marriage, and many other ill practices of the society which has disturbed the sense of balance of women in the society and had oppressed them intellectually the time has healed their wounds, today's woman is much stronger, confident, intelligent and organizer of the modern society.

\section{The Plan of Research}

The Plan of research is discussed in the following three sections.

(A) Objectives of the study: The objectives of the study intends to analyze the status of Muslim women in the city of Bhopal concerning their exposure to Mass Media and education. Such as:

1. To assess the utilization pattern of the mass media towards modernization of the respondents.

2. To examine the hindrances of Muslim Women in mass media exposure and stoppages of being modern.

(B) Hypothesis of the Study: the following hypotheses of our study

1. It is hypnotized that mass media exposure leads to the modernization of society.

2. It is assumed that educated Muslim women are well versed with media exposure.

3. It is assumed that mass media plays a vital role in modernizing the attitude of Muslim women towards education.

\section{Research Methodology and Area of Study:}

So for the collection of data is concerned which is based on the sources such as direct and indirect sources. The former represents the primary data that was collected from the respondents; the latter represents the secondary data that was collected from textbooks, newspapers, periodicals, publications, websites, journals, etc. The techniques used in this research is based on the sampling method and interview. 


\section{International Journal of Social Science and Economic Research}

ISSN: $2455-8834$

Volume:06, Issue:02 "February 2021"

\section{Sampling procedure:}

To collect data and information, the study of a sample of three hundred (300) respondents were selected from the concerned field work area of District Bhopal. For in-depth study, three hundred samples of educated Muslim women of graduate/undergraduate/postgraduate level comprising of students, working ladies, housewives from different sectors of the society like educational institutions, offices, houses wives would be selected randomly for the study. The selected district is constituted of numerous educational institutions with almost a bulk student, out of which we will select different colleges especially samples will be collected from women colleges for the present study. The samples were randomly selected from the selected colleges of District Bhopal. Before interviewing the respondents, a thorough study was conducted in the area to collect the necessary information. There are many research designs to carry out the research or fieldwork on a particular type of research problem such as experimental research design, descriptive research design, and exploratory research design. As far as our research is concerned, descriptive research, the design have been used in the present work. The data available to us revealed that our problem can be studied further for more research work as has been suggested by exploratory research design.

\section{Area of Study:}

Madhya Pradesh is a state in central India having 51 districts. Located in the heart of Madhya Pradesh, the historical city of Bhopal is deservingly the capital of the state. Besides the excellent location of Bhopal, the city is blessed with beautiful landscapes, busy profitable canters, peaceful residential areas, and historical monuments. The geographical location of Bhopal City lies within North Latitude $23^{\circ} 16^{\prime}$ and East Longitude $77^{\circ} 36^{\prime}$. The location of Bhopal falls in the northwestern portion of Madhya Pradesh. If seen in the Map of India, Bhopal occupies the centralmost region of the country. The city of Bhopal shares its border with two large and picturesque lakes. Like few other big cities of the country, Bhopal is also divided into two parts - the old city and the new one. The Old Bhopal is situated in the northern part of the city, while the southern part is called the New Bhopal. The two lakes of Bhopal City are referred to as the Upper and the Lower Lakes (Source: Report by UDD, Government of MP and BMC, 2012).=

\section{RESULT AND DISCUSSIONS}

Education is one of the necessities of life and it paves the way to a successful career. Studies show that in most cases, a successful career comes from a healthy education. There is a clear correlation between education and success. A career is a course or progress through life and is seen as a sequence of related jobs. Family support is of utmost importance in women's careers and education. The importance of education for every person is to live independently and to gain freedom irrespective of caste, creed, and gender. It develops good citizens among the society and 
promotes self-respect and raises status. Women should be equally educated along with men and prove women's empowerment. When a woman is educated it not only affects her but the whole society and as well as the nation is affected.

\section{Muslim community's perception about women education and empowerment}

A community is a social unit or a group of persons that has some common characteristics like norms, religion, identity, or values. Here we discuss the Muslim community because the population in this research work comprises only educated Muslim women. Most of the Muslim women are not clear about their rights given in Islam as a religion as well as in the Indian constitution; however, perception of the said community has been grouped as negative, positive, restrictive, neutral, and undecided in our study as shown in Table 01.

Table 01Muslim community's perception about women education And empowerment

\begin{tabular}{|c|c|c|c|}
\hline S.No. & $\begin{array}{c}\text { How is your community's general } \\
\text { perception of women's education and } \\
\text { empowerment? }\end{array}$ & Frequency & Percentage \\
\hline 1 & Negative & 16 & 5.33 \\
\hline 2 & Positive & 234 & 78.00 \\
\hline 3 & Restrictive & 11 & 3.67 \\
\hline 4 & Neutral & 38 & 12.67 \\
\hline 5 & Un decided & 1 & 0.33 \\
\hline & Total & $\mathbf{3 0 0}$ & $\mathbf{1 0 0}$ \\
\hline
\end{tabular}

Table 01 shows that majority of the respondents that is 78 percent sense a positive approach from the respective community regarding education and empowerment. Marginal 5.33 percent of the respondents feel negative approach, 3.67 feel restrictive approach while 12.67 percent feel neutral approach. Rest 0.33 percent of the respondents were undecided about the perception of the community about women's education and empowerment. It is undoubtedly a positive sign that the Muslim community has transformed positively and their approach regarding education and empowerment of Muslim women has changed to positivity. 


\section{Restriction about education and career}

Muslim women are considered as backward sections of the people as far as education is concerned. It is because of the reason that Muslim women are not allowed freely to go outside the home which hinders their education and career. Also, early marriage is one of the important factors responsible for the same. Now the traditional trend is changing and the participation of Muslim women in education and other sectors is on the rise and the data collected regarding the captioned case can be analyzed in Table 02 .

Table.02Restriction about education and career

\begin{tabular}{|c|c|c|c|}
\hline S.No. & $\begin{array}{c}\text { Do you face any restrictionsabout } \\
\text { education and career, being a Muslim } \\
\text { woman? }\end{array}$ & Frequency & Percentage \\
\hline 1 & No & 202 & 67.33 \\
\hline 2 & Yes & 49 & 16.33 \\
\hline 3 & Sometimes & 44 & 14.67 \\
\hline 4 & Can't say & 5 & 1.67 \\
\hline & Total & $\mathbf{3 0 0}$ & $\mathbf{1 0 0 . 0 0}$ \\
\hline
\end{tabular}

Table 02 shows that 67.33 percent of the respondents feel free to pursue education and make a career. 16.33 percent of the respondents still face restriction about education and career while 14.67 percent feel some kind of restriction and 1.67 percent of the respondents did not say anything on the subject issue. Analysis of the data shows that Muslim women in Bhopal do not face restrictions about education and career. They are not deprived of the fundamental rights of education.

\section{Modernization}

In sociology, modernization refers to the transformation from pre-modern (rural or traditional) society to modern (secular or industrial) society. It is an open-ended and continuous process that keeps on changing and upgrading. To analyze what respondents consider modernization, it has been grouped into four main categories of educational, economic, political, and personality development. The data has been distributed in Table 03 
International Journal of Social Science and Economic Research

ISSN: 2455-8834

Volume:06, Issue:02 "February 2021"

Table 03 Modernization means

\begin{tabular}{|c|c|c|c|}
\hline S.No. & $\begin{array}{c}\text { What according to you,does } \\
\text { modernization mean? }\end{array}$ & Frequency & Percentage \\
\hline 1 & Educational development & 62 & 20.67 \\
\hline 2 & Economic development & 13 & 4.33 \\
\hline 3 & Political development & 3 & 1.00 \\
\hline 4 & Personality development & 16 & 5.33 \\
\hline 5 & $1+2$ & 2 & 0.67 \\
\hline 6 & $2+3$ & 9 & 3.00 \\
\hline 7 & $3+4$ & 1 & 0.33 \\
\hline 8 & $1+2+3+4$ & 3 & 63.67 \\
\hline 9 & Others & $\mathbf{3 0 0}$ & $\mathbf{1 0 0 . 0 0}$ \\
\hline & Total & & \\
\hline
\end{tabular}

Table 03 shows that 63.67 percent of the respondents consider educational, economic, political, and personality development as pillars of modernization. 20.67 percent of the respondents consider only educational development as modernization, 4.33 percent consider economic development and one (1) percent consider political development and 5.33 percent consider personality development respectively as individual factors leading to the modernization of society. 0.67 percent, 3 percent, and 0.33 percent of the respondents consider a combination of two different above-stated developments as modernization. The remaining one (1) percent of the respondents consider other than stated developments as modernization. While analyzing the outcome of the data, it depicts that respondents have a better understanding of modernization.

\section{Impact of modernization on general aspects of life}

The impact of modernization is quite visible in our day-to-day life, as it has changed the lifestyle of almost every human being living in modern societies. Education, culture, communication, and 
social relations have undergone enormous changes. Modernization had a great impact on the Muslim community as well. Opinion regarding the impact of modernization is shown in Table 04

Table 04 Impact of modernization on general aspects of life

\begin{tabular}{|c|c|c|c|}
\hline S.No. & $\begin{array}{c}\text { Do you agree that modernization has an } \\
\text { impact on general aspects of life? }\end{array}$ & Frequency & Percentage \\
\hline 1 & Strongly disagree & 5 & 1.67 \\
\hline 2 & Disagree & 15 & 5.00 \\
\hline 3 & Neither & 6 & 2.00 \\
\hline 4 & Agree & 172 & 57.33 \\
\hline 5 & Strongly agree & 102 & 34.00 \\
\hline & Total & $\mathbf{3 0 0}$ & $\mathbf{1 0 0 . 0 0}$ \\
\hline
\end{tabular}

Table 04 discloses that 57.33 percent of the respondents agree and 34 percent strongly agree that modernization has influenced life. 5 percent and 1.67 percent of the respondents disagree and strongly disagree respectively that modernization has an impact on life. Only 2 percent of the respondents neither agree nor disagree on the subject issue. Data collected for the captioned purpose depicts that modernization has become an integral part of society and has a great impact on every aspect of life.

\section{Definition of the modern woman}

A modern woman is described as independent, self-reliant, confident, self-aware, steadfast, etc. A modern woman could achieve her goals and maintain a strong household without the support of a man. She wants to be at par with men in every field of life by breaking traditional barriers which she used to be facing in ancient times. The definition of the modern woman has been described through five features as shown in Table 05.

Table 05 Definition of the modern woman

\begin{tabular}{|c|c|c|c|}
\hline S.No. & $\begin{array}{c}\text { What according to you modern } \\
\text { woman means? }\end{array}$ & Frequency & Percentage \\
\hline 1 & Well educated & 52 & 17.33 \\
\hline
\end{tabular}


International Journal of Social Science and Economic Research

ISSN: 2455-8834

Volume:06, Issue:02 "February 2021"

\begin{tabular}{|c|c|c|c|}
\hline 2 & Economic well off & 17 & 5.67 \\
\hline 3 & Social exposure & 12 & 4.00 \\
\hline 4 & Independent & 9 & 3.00 \\
\hline 5 & Self-reliant & 4 & 1.33 \\
\hline 6 & All of the above & 191 & 63.67 \\
\hline 7 & None of the above & 15 & 5.00 \\
\hline & Total & $\mathbf{3 0 0}$ & $\mathbf{1 0 0 . 0 0}$ \\
\hline
\end{tabular}

Table 05describes the modern woman and it is found that 63.67 percent of the respondents consider modern woman as well educated, economically well off, socially exposed, independent and self-reliant. 17.33 percent, 5.67 percent, 4 percent, 3 percent, and 1.33 percent of the respondents consider a modern woman with individual features of well educated, economic well off, social exposure, independence, and self-reliance respectively. The remaining 5 percent of the respondents consider a woman with other than the above-stated features. Hence it can be concluded from the above-tabulated data that the majority of the respondents hold a modern woman with all five features.

\section{Modernization and escalation in harassment issues}

One of the important blessings of modernization is equal recognition of the status of women. Nowadays, men and women work together and earn a respectable living in society, but on the other hand, women are often subjected to harassment and ill-treatment by their colleagues and co-workers. Modernization has also given rise to crimes especially against women folk by way of rapes, exploitation, sexual harassment, and many more. Here in below-mentioned table 4.19, we try to get a general outlook regarding the correlation between modernization and harassment issues.

Table 06 Modernization and escalation in harassment issues

\begin{tabular}{|c|c|c|c|}
\hline S.No. & $\begin{array}{c}\text { Modernization has increased harassment } \\
\text { issues related to womenfolk. }\end{array}$ & Frequency & Percentage \\
\hline 1 & Strongly disagree & 7 & 2.33 \\
\hline
\end{tabular}


International Journal of Social Science and Economic Research

ISSN: 2455-8834

Volume:06, Issue:02 "February 2021"

\begin{tabular}{|c|c|c|c|}
\hline 2 & Disagree & 25 & 8.33 \\
\hline 3 & Neither & 50 & 16.67 \\
\hline 4 & Agree & 186 & 62.00 \\
\hline 5 & Strongly agree & 32 & 10.67 \\
\hline & Total & $\mathbf{3 0 0}$ & $\mathbf{1 0 0 . 0 0}$ \\
\hline
\end{tabular}

From Table 06, it is revealed that 62 percent of the respondents agree that modernization has increased harassment issues, 10.67 percent strongly agree while 16.67 percent of the respondents neither agreed nor disagreed with the subject case. Only 8.33 percent and 2.33 percent of the respondents disagree and strongly disagree that modernization has increased harassment issues related to women which implies that nearly seventy-three percent of the samples think that modernization has given escalation to harassment issues and crimes particularly molestation, rape, sexual harassment, bareness any many other issues. Hence, advantages of modernization go parallel with disadvantages as per interpretations of the women.

\section{Impact of modernization on Muslim women}

The strongest impact of modernization is the awakening of woman's consciousness. The role of women is changing from submissive to a modern one, demanding, independent, and sovereign. Modernization has increased the educational volume of women, empowerment, and improvement in rights and values, and above all relaxation in traditional social restrictions. On the other hand, negative effects can also be seen such as degradation of moral values, westernization, rise in gender crimes, etc. The impact of modernization has been categorized into five groups as shown in Table 07.

Table 07 Impact of modernization on Muslim women

\begin{tabular}{|c|c|c|c|}
\hline S.No. & $\begin{array}{c}\text { What is the impact of modernization on } \\
\text { educated Muslim women? }\end{array}$ & Frequency & Percentage \\
\hline 1 & Increase in education volume & 78 & 26.00 \\
\hline 2 & Empowerment of women & 49 & 16.33 \\
\hline 3 & Improvements in rights \& values & 120 & 40.00 \\
\hline
\end{tabular}


International Journal of Social Science and Economic Research

ISSN: 2455-8834

Volume:06, Issue:02 "February 2021"

\begin{tabular}{|c|c|c|c|}
\hline 4 & Relaxation in social restrictions & 8 & 2.67 \\
\hline 5 & The decrease in moral values & 45 & 15.00 \\
\hline & Total & $\mathbf{3 0 0}$ & $\mathbf{1 0 0 . 0 0}$ \\
\hline
\end{tabular}

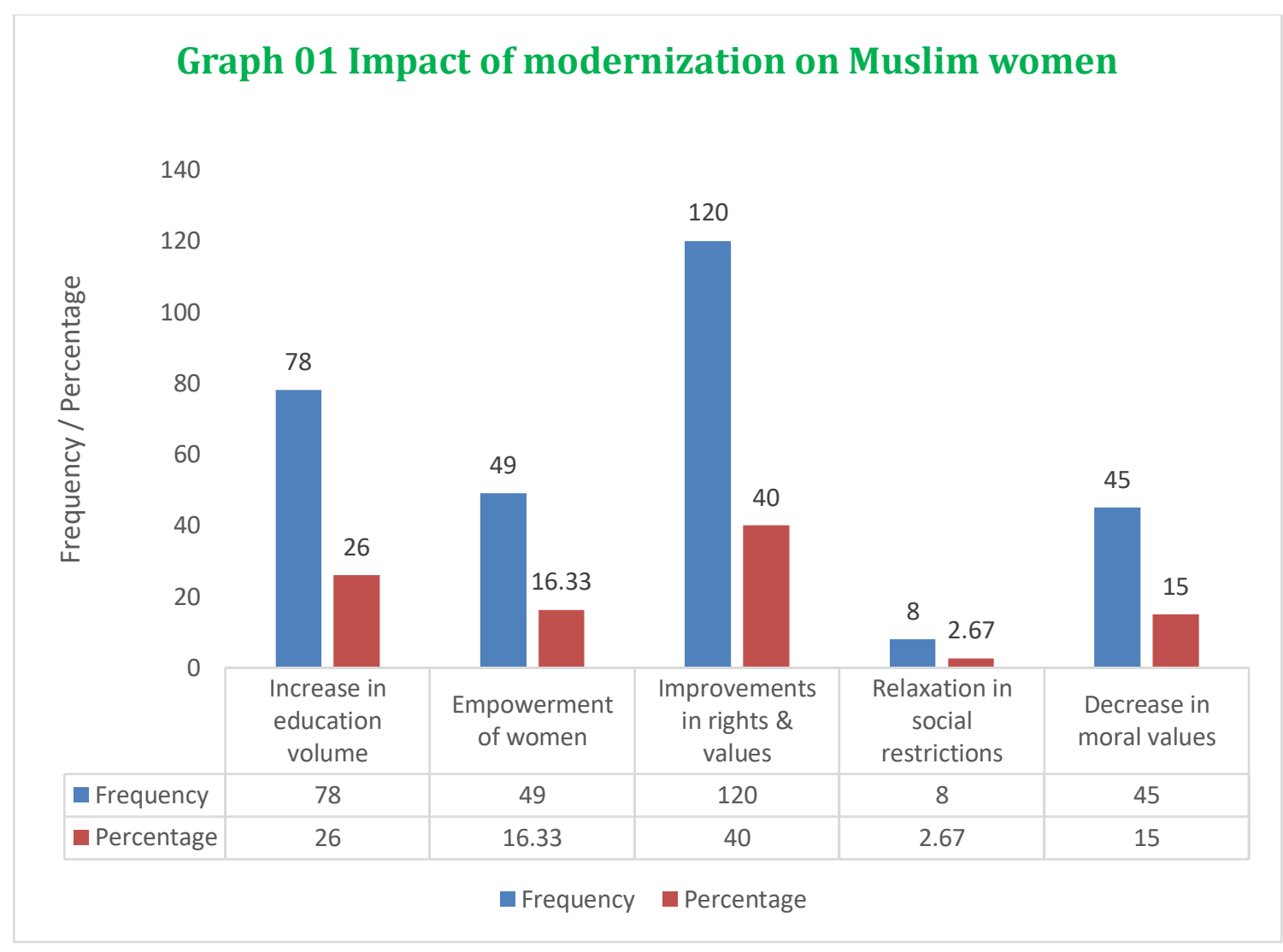

Table 07 reveals that 26 percent of the respondents consider an increase in education volume is the impact of modernization on Muslim women. 16.33 percent of the respondents feel that women empowerment has a strong impact on modernization while 40 percent of the respondents hold modernization responsible for the improvement in rights and values of women. Only 2.67 percent of the respondent's fee relaxation in social restriction after modernization. Fifteen (15) percent of the respondents feel the negative impact of modernization as they experience degradation of moral values due to modernization. It can be concluded that modernization has more positive effects than negative.

Family restriction on mass media consumption 
A Muslim woman is mostly pictured as different, exotic, and even a symbol of backwardness. She faces restrictions in public areas, movement in domestic space even in their own families. They are usually considered as homemakers and are considered inferiors to male genders and their wills and ambitions are given the least importance. From the above-collected data, it is found that time has changed and now Muslim women are living in a much better environment and conditions. Responses have been shown in table 08 .

Table 08 Family restriction on mass media consumption

\begin{tabular}{|c|c|c|c|}
\hline S.No. & $\begin{array}{c}\text { Do you have family restrictions in } \\
\text { using mass media patterns? }\end{array}$ & Frequency & Percentage \\
\hline 1 & No & 194 & 64.67 \\
\hline 2 & Yes & 42 & 14.00 \\
\hline 3 & Sometimes & 64 & 21.33 \\
\hline & Total & $\mathbf{3 0 0}$ & $\mathbf{1 0 0 . 0 0}$ \\
\hline
\end{tabular}

Table 08 highlights that the majority of the respondents i.e. 64.67 percent of the respondents do not feel any kind of restriction from family while using mass media but 14 percent of the respondents still face restrictions from families while consuming mass media patterns and the rest 21.33 percent of the respondents face sometimes restrictions from families on the subject issue. It indicates that Muslim women are not restricted by respective families in using mass media which gives them space to explore more opportunities for achieving respectable status in society.

\section{Phases of transformation due to mass media exposure}

Media affects our lives because it has the power to influence our thoughts which may be positive and negative as well. Media can affect the way people are viewed, which means people's careers and savors can change within a flash. It can also manipulate people to lead their life a particular way and change the mindset and viewpoint of life. In this case, some universal stages of life have been identified and the opinion of the respondents regarding their insight towards those phases has been shown in Table 09 given as under. 
International Journal of Social Science and Economic Research

ISSN: 2455-8834

Volume:06, Issue:02 "February 2021"

Table 09 Phases of Transformation due to mass media exposure

\begin{tabular}{|c|c|c|c|}
\hline S.No. & $\begin{array}{c}\text { Life has transformed into which of the } \\
\text { following phases due to global mass media } \\
\text { exposure? }\end{array}$ & Frequency & Percentage \\
\hline 1 & Easy \& Comfortable & 127 & 42.33 \\
\hline 2 & Fast \& Complex & 133 & 44.33 \\
\hline 3 & Fearful \& Risky & 17 & 5.67 \\
\hline 4 & Luxurious \& Glamorous & 23 & 7.67 \\
\hline & Total & $\mathbf{3 0 0}$ & $\mathbf{1 0 0 . 0 0}$ \\
\hline
\end{tabular}

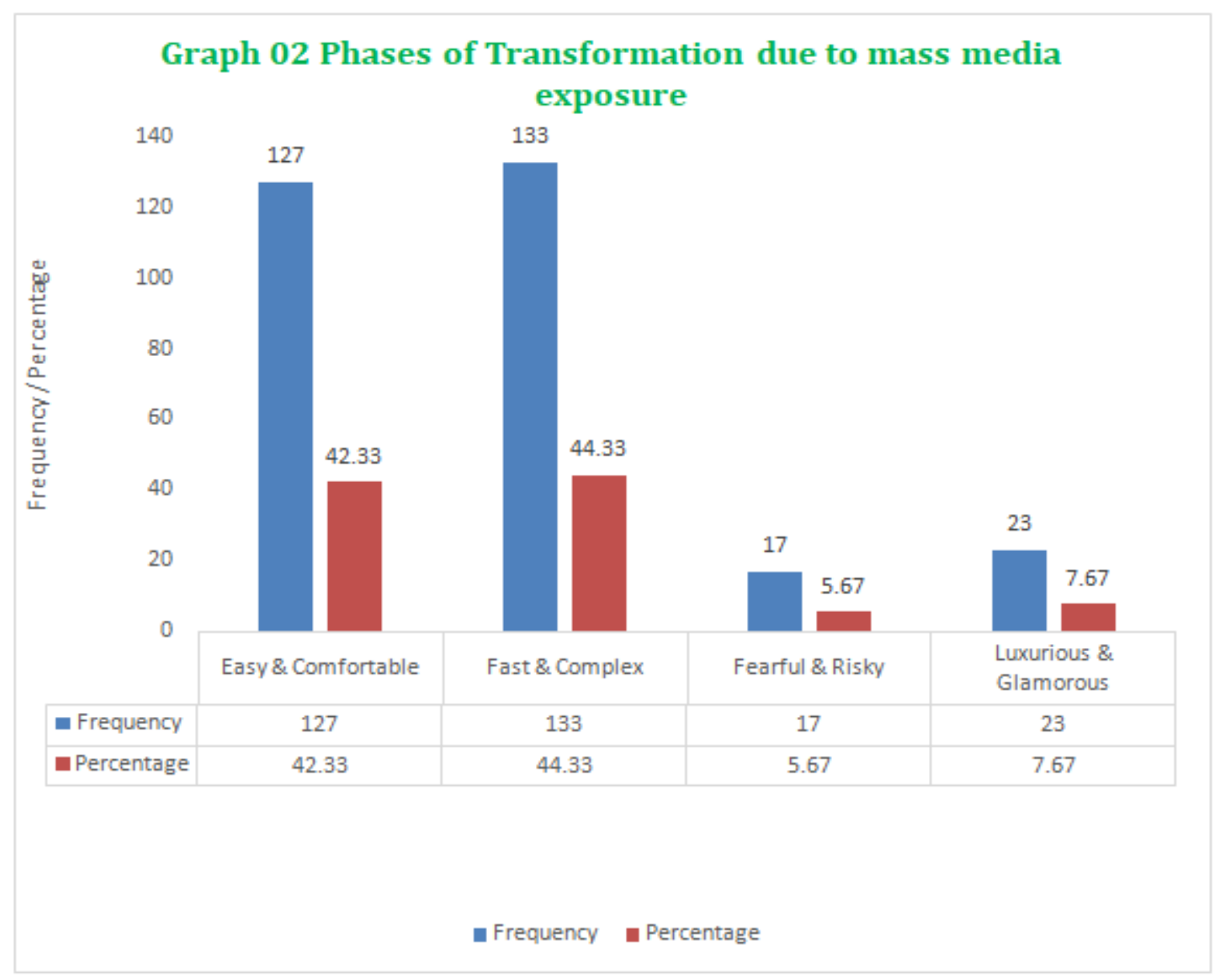


Table 09 describes the different stages of life and data collected shows that 44.33 percent of the respondents felt that life has changed into the fast and complex mode with global mass media exposure as people complicate their lives by taking extra tasks to make ends meet or get ahead. Almost the same quantity of 42.33 percent of the respondents considers that life has turned into an easy and comfortable stage due to unlimited facilities available at a doorstep. 5.67 percent of the respondents suggest that it's a fearful and risky stage of life due to the reason being people exploiting technologies for personal gains thereby posing a threat to people at large. Contrary to this, 7.67 percent of the respondents hold life as luxurious and glamorous due to mass media exposure.

\section{Women issues addressed by media}

When it comes to media and women's issues, it is every single one of us who can get involved and can amplify women's voices successfully and achieve equality. Educated Muslim women in Bhopal utilize social media to mobilize public attention to enhance the visibility of issues that often get lost in mainstream media. They also take part in conversations on their rights issues and raise voices to address them, may it be issues like forced marriage, family violence, gender inequality, negative stereotype, etc. Table 10 shows responses addressing women's issues.

Table 10 Women issues addressed by media

\begin{tabular}{|c|c|c|c|}
\hline S.No. & $\begin{array}{c}\text { What issues do you think that women can } \\
\text { address most effectively with increasing } \\
\text { participation in media? }\end{array}$ & Frequency & Percentage \\
\hline 1 & Career-related & 15 & 5.00 \\
\hline 2 & Gender inequality & 60 & 20.00 \\
\hline 3 & Harassment \& exploitation & 112 & 37.33 \\
\hline 4 & Social \& cultural & 87 & 8.67 \\
\hline 5 & All of the above & $\mathbf{3 0 0}$ & $\mathbf{1 0 0 . 0 0}$ \\
\hline
\end{tabular}

Table 10 highlights some basic issues related to women folk and the impact of participation by women in media to address them. Figures of the table show that 37.33 percent of the respondents felt that harassment and exploitation issues could be allocated through media participation 
because it reaches a large audience in a quick time. 8.67 percent of the respondents think social and cultural issues can be better addressed through media participation while five (5) percent of the respondents suggest that career-related issues can be resolved by mass media exposure. Twenty-nine (29) percent of the respondents hold mass media as a useful tool in resolving all the above-stated issues.

\section{Women empowerment due to internet and media patterns}

Women empowerment refers to the creation of an environment for women where they can make decisions of their own for their benefits as well as for society. Today, technology directly impacts women's development and has enabled their voices to reach out and be viewed globally. In a recent report published by Google, it is clear that the internet is empowering Indian women with easy access to information and helping them to make more up-to-date decisions in their day-to-day life. Table 11 reveals whether the internet and media can play a role in women's empowerment.

Table 11 Women empowerment due to internet and media patterns

\begin{tabular}{|c|c|c|c|}
\hline S.No. & $\begin{array}{c}\text { Due to easy access tothe internet and media } \\
\text { patterns, do you agree that women have } \\
\text { empowered? }\end{array}$ & Frequency & Percentage \\
\hline 1 & Strongly disagree & 4 & 1.33 \\
\hline 2 & Disagree & 32 & 10.67 \\
\hline 3 & Neither & 27 & 9.00 \\
\hline 4 & Agree & 211 & 70.33 \\
\hline 5 & Strongly agree & 26 & 8.67 \\
\hline & Total & $\mathbf{3 0 0}$ & $\mathbf{1 0 0 . 0 0}$ \\
\hline
\end{tabular}

Table 11 shows that 70.33 percent and 8.67 percent of the respondents agree and strongly agree that internet access and media patterns have empowered women respectively. The status of women has improved concerning equal rights, social status, and freedom from oppression and dominance. Only 1.33 percent and 10.67 percent of the respondents strongly disagree and only disagree with the subject statement as they do not feel such kind of change in their respective lives. Nine (9) percent of the respondents neither agree nor disagree with the same. It describes 


\section{International Journal of Social Science and Economic Research}

ISSN: $2455-8834$

Volume:06, Issue:02 "February 2021"

that more than $3 / 4^{\text {th }}$ of the samples think that internet and media patterns provide more knowledge about their rights and powers that every woman in a society holds in every respect. All these positive changes are now activated to only increase their pace with time. According to a report released in June 2013, titled "Women and Web Study", out of a total 150 million Internet users in India, more than 60 million women use the Internet to manage their day-to-day life.

\section{Conclusion}

The strongest impact of modernization is the awakening of woman's consciousness. The role of women is changing from submissive to a modern one, demanding, independent, and sovereign. Modernization has increased the educational volume of women, empowerment, and improvement in rights and values, and above all relaxation in traditional social restrictions. Technology directly influences women's development and has enabled their voices to reach out and be viewed globally. In a recent report published by Google, it is clear that the internet is empowering Indian women with easy access to information and helping them to make more upto-date decisions in their day-to-day life. The status of women has improved concerning equal rights, social status, and freedom from oppression and dominance. It describes that more than $3 / 4^{\text {th }}$ of the samples think that internet and media patterns provide more knowledge about their rights and powers that every woman in a society holds in every respect. All these positive changes are now activated to only increase their pace with time. According to a report released in June 2013, titled "Women and Web Study", out of a total 150 million Internet users in India, more than 60 million women use the Internet to manage their day-to-day life. Muslim women are considered as backward sections of the people as far as education is concerned. It is because of the reason that Muslim women are not allowed freely to go outside the home, which hinders their education and career. In addition, early marriage is one of the important factors responsible for the same. Now the traditional trend is changing and participation of Muslim women in education and other sectors is on the rise.

\section{Bibliography}

1. Aggarwal, \& V. B. (2002). Women and Human Rights: A case for Gender Sensitization. Communication today. Concept Publishing Company.

2. Anderson, D. C., \& Sharrock, W. W. (1979). Biasing the News: Technical Issues in Media Studies'. Sociology, 13(3), 367-385.

3. Anita, N. (2010), Programmes and Schemes for Education of Minorities: Evaluation of Area Intensive Scheme. New Delhi: Serial Publication, 70-85. 
International Journal of Social Science and Economic Research

ISSN: 2455-8834

Volume:06, Issue:02 "February 2021"

4. Ansari A., Iqbal (1979) Muslim Personal Law in India, Institute of Muslim Minority Affairs, Vol 1 No.2, 86- 96.

5. Arpita Sharma (2012): Harnessing Potential of Community Radio for Rural Advancement. Kurukshetra. January 2012. P. 18-23.

6. Bhatty and Zarina (1976), Status of Muslim Women and Social Change. In B.R.Nanda (Ed.), Indian Women: From Purdah to Modernity, Delhi: Vikas Publication House.

7. Carrol, L. (1983), The Muslim Family in India: Law, Custom and Empirical Research, Contributions to Indian Sociology, Vol.17 No.2, 205-222.

8. Chand, Suresh, and Singh, Kulwinder (2002): Media and Literacy Movement in India: Some Critical Issues. IN: Media and Society: Challenges and Opportunities. Edited by Vir Bala Aggarwal. New Delhi: Concept Publishing, 2002. P. 127-131.

9. Engineer Asghar Ali. (1995). Introduction: Problems of Muslim Women in India, Hyderabad, Orient Longman.

10. Engineer, Asghar Ali. (2008). Rights of Women in Islam (Third Edition) (New Delhi, Sterling Publishers Pvt. Ltd.

11. Farida Khan and RehanaGhadially (2009): Gender-differentiated Impact on Minority Youth of Basic Computer Education in Mumbai City. Gender, Technology, and Development. Vol. 13. No. 2. 2009. P. 245-269.

12. Farouqui, Ather. (2009). Muslims and Media Images: News versus Views (New Delhi, Oxford University Press.

13. JahanYasmin. et.al (2017) Trends in mass media exposure upon women: A review of Bangladesh Demographic and Health Survey. Global Journal of Medicine and Public Health. Vol. 6, issue 2.

14. Johnson, Kirk (2001): Media and Social Change: The Modernizing Influences of Television in Rural India. Media, Culture and Society, Vol. 23. No. 2. 2001. P. 147-169.

15. Mishra, L. (1993). Women's issues: An Indian Perspective.New Delhi: Northern India.

16. Myneni, S. R. (2005). Woman and the Law, Asia Law house publication, ed., Hyderabad, pp. 1,2 . 
17. Rabi, A. (2015). Modernization of Islamic world Retrieved from https://www.beliefnet.com/faiths/islam/2001/10/modernization-of-the-islamic-world.aspx.

18. Sharif, A.S., (2003). Some Socio-Economic and Demographic Aspects of Population According to Religion in India, Bombay, Centre for Study of Society and Secularism.

19. Sharma, Rashmi (2009): Women Development: New Approaches and Innovations. New Delhi: New Elegant Enterprises, 2009.

20. Waheed, A., Sayeed, A., \&Mujtaba, S. I. (2014). Empowerment of Muslim Women in India: A Sociological Analysis. Bangladesh e-Journal of Sociology, 11(2), 41.

21. Wijesundra, Tilak (2011): Indian Mass Media: A Sociological Analysis. International Journal of Communicology. Vol. 1. No. 1. 2011. P. 20-30.

22. Yellaiah, J and Sushila, A (2013): ICT Education for Rural Women and Girls: A Case of Computer Education. Indian Journal of Applied Research. Vol. 3. No. 3. March 2013. P. 6971. 